\title{
Yield components and nutritional quality of soybean grain as a function of foliar fertilizers application time
}

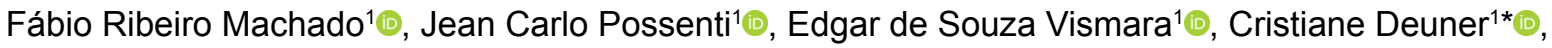 \\ Vitor Rampazzo Favoretto² ${ }^{2}$, Fabiana Ribeiro Machado ${ }^{3}$

\footnotetext{
${ }^{1}$ Universidade Tecnológica Federal do Paraná, Programa de Pós-Graduação em Agronomia, Pato Branco, PR, Brasil. E-mail: fabio_rmachado@yahoo.com.br; jpossenti@utfpr.edu.br edgarvismara@utfrr.edu.br; cdeuner@yahoo.com.br

${ }^{2}$ University of Illinois at Urbana-Champaign, Crop Sciences Department, Urbana, IL, Estados Unidos. E-mail: vrf@illinois.edu

${ }^{3}$ Universidade Estadual do Oeste do Paraná, Programa de Pós-Graduação em Agronomia, Marechal Cândido Rondon, PR, Brasil, E-mail: fabrm2015@gmail.com
}

ABSTRACT: Foliar fertilization aims to provide rapid-absorption nutrients to the plant, supplement soil fertilization, and fulfill the uptake peaks' demand. This study's objective was to verify the effect of foliar fertilizers application in stages R2 (full bloom) and R5 (beginning seed) on soybean grain quality, yield components, and grain yield. The experiment was conducted in three sites through Parana state (Brazil) in a $9 \times 2$ factorial design, with three replications per treatment. Total chlorophyll index, plant height, yield components (number of pods per plant, number of grains per pod, number of grains per plant and thousand-grain mass), protein and oil concentration in the grain, and final yield were evaluated. Plant height, total chlorophyll index, and grain quality were not affected by this study's foliar fertilizers. Thousand-grain mass responded to the foliar products and the application times. However, no final grain yield effect was observed, possibly because those nutrients' soil level was adequate.

Key words: fertilization; Glycine max; yield

\section{Componentes de rendimento e qualidade nutricional do grão de soja em função da época de aplicação de adubos foliares}

RESUMO: A adubação foliar visa fornecer às plantas nutrientes de absorção rápida, complementando a adubação via solo e atendendo as demandas das culturas nos momentos de maior exigência. Objetivou-se com o estudo verificar 0 efeito da aplicação de fertilizantes foliares nos estádios fenológicos R2 (pleno florescimento) e R5 (enchimento de grão) sobre a qualidade do grão, os componentes de rendimento e a produtividade da soja. $O$ experimento foi conduzido em três locais no estado do Paraná, em esquema fatorial $9 \times 2$, com três repetições por tratamento. Foram avaliados 0 índice total de clorofila, altura da planta, componentes de rendimento (número de vagens por planta, número de grãos por vagem, número de grãos por planta e massa de mil grãos), teor de proteína e óleo no grão e produtividade. A altura das plantas, o índice total de clorofila e a qualidade dos grãos não foram afetados pelos fertilizantes foliares aplicados neste estudo. A massa de mil grãos respondeu aos produtos foliares e época de aplicação. No entanto, nenhum efeito no rendimento final foi observado, possivelmente, pelos teores adequados dos nutrientes no solo.

Palavras-chave: fertilização; Glycine max; produção

\footnotetext{
* Cristiane Deuner - E-mail: cdeuner@yahoo.com.br (Corresponding author)

Associate Editor: Adônis Moreira
} 


\section{Introduction}

The soybean crop (Glycine max (L.) Merrill) is currently one of the world's most spread. It has a high protein level (almost $40 \%$ of the grain weight), as well as valuable oils and mineral compounds (Kahraman, 2017), being used as soybean meal and other industrial products that supply a big part of the nutritional needs for the world population, which makes soybean a crop with great economic importance. Thus, the search for higher yields and grain quality in the soybean fields has been constant in physiological terms like in chemical components and in its protein and oil concentrations in the grain, influencing its industrial quality.

The composition of the soybean grain differs depending on the variety, the environment, and the agricultural practices, especially fertilization (Campo et al., 2009; Possenti \& Villela, 2010). The leading cause for low yields is a multi-nutrient deficiency. Growers tend to provide only nitrogen and phosphorus to the main cultivated crops, and frequently in lower doses than recommended (Kahraman, 2017). In the last crop seasons, this fact had motivated farmers and technicians to utilize foliar fertilizers to supply the crop's demands in the peak of uptake because it has the highest requirement. Foliar fertilizers are composed of macro and micronutrients in the solid form with high solubility or in liquid form. They have the objective to provide the plants with nutrients of rapid absorption, complement the fertilization via soil, providing the nutrients when the plant needs, avoiding and correcting deficiencies (Musskopf \& Bier, 2010).

To the usage of this technology, there are currently in the market numerous commercial products. Still, the research institutions' experimental results have shown high variability in soybean response from the application of those products. Foliar fertilizers applied at different phenological stages of soybean culture did not affect grain yield and its main yield components in a study by Batista et al. (2017). On the other hand, an increase in the number of pods and grains per plant through foliar fertilizers, and consequently increased productivity, was observed by Meschede et al. (2008). Although the majority of these products have a micronutrient base, the macronutrients had also had their importance and as an example, the nitrogen (N) (Mourtzinis et al., 2018; Craft et al., 2019), one of the primary nutrients necessary for the growth and development of soybean (Gai et al., 2017). Besides, assessing fertilization practices that cause biological contamination is critical, mainly because the environment's concern is growing. The use of nitrogen-based foliar fertilizers has been commercially recommended, frequently, as a possible alternative to supplementing soil fertilization. Research studies have also supported those indications (Marcon et al., 2017; Buratto et al., 2018; Craft et al., 2019). However, Mourtzinis et al. (2018) concluded that soybeans had a minimal response in the yield to $\mathrm{N}$ applied both in the soil and in a foliar way. Thus, the practice of foliar applying this nutrient is controversial and commonly results in conflicting results. The classic study of plants' fertility and physiology teaches that plants have specialized organs to absorb nutrients in higher quantities, the roots (Malavolta et al., 1997; Taiz et al., 2017).

Thus, it is fundamental for success to be obtained using this technology to know when to use it, which nutrients, time, and doses to be applied. In this context, the present study had as objective to verify the possible influences of different foliar fertilizers applied in two distinct growth stages, full bloom and beginning seed in soybean yield and protein and oil concentration in the grain.

\section{Materials and Methods}

The present study was divided into three field trials, made in three different sites in Parana state (Brazil). One in the southwest region in the town of Santa Izabel do Oeste (509 $\mathrm{m}$ of altitude) and two in the west part of the state, being one in the city Capitão Leônidas Marques (Capitão) (320 m of altitude) and the other in Juvinópolis (707 m of altitude), district of Cascavel town. The seeding was done in Juvinópolis on October $5^{\text {th }}$, in Capitão on October $20^{\text {th }}$, and in Santa Izabel on October $28^{\text {th }}$.

The chosen experimental areas had been under a no-till system for more than ten years. The BMX Turbo R.R. variety was used, with a planting density of 26.5 seeds $\mathrm{m}-2$. The base fertility was done with a $300 \mathrm{~kg}$ ha- 1 dose of the commercial formula 02-20-20 (NPK: Nitrogen, $\mathrm{P}_{2} \mathrm{O}_{5}$ and $\mathrm{K}_{2} \mathrm{O}$ ). Tables 1 and 2 are the soil chemical characterization for each site.

The field trials were implemented with a complete randomized block design, with a $9 \times 2$ two-way factorial, with three replications. The first factor with nine levels reflected in applying the foliar fertilizer, one untreated check (with no foliar fertilizer), and eight different commercial products, specified in Table 3.

Table 1. Chemical soil characterization (macronutrient level, potential acidity, base saturation, and aluminum) in each site before installing each trial.

\begin{tabular}{|c|c|c|c|c|c|c|c|c|c|c|c|c|}
\hline \multirow{2}{*}{ Site } & \multirow{2}{*}{$\begin{array}{l}\text { Depth } \\
\text { (cm) }\end{array}$} & $\mathbf{P}$ & $\mathrm{s}$ & $\mathrm{H}+\mathrm{Al}^{+}$ & $\mathbf{A l}^{\mathbf{3 +}}$ & $\mathrm{K}^{+}$ & $\mathrm{Ca}^{2+}$ & $\mathrm{Mg}^{2+}$ & SB & CEC & v & $\mathrm{Al}$ \\
\hline & & \multicolumn{2}{|c|}{$\left(\mathrm{mg} \mathrm{dm}^{-3}\right)$} & \multicolumn{7}{|c|}{$\left(\mathrm{cmol}_{c} \mathrm{dm}^{-3}\right)$} & \multicolumn{2}{|c|}{ (\%) } \\
\hline \multirow{2}{*}{ Juvinópolis } & $0-10$ & 10.9 & 6.3 & 5.7 & 0.0 & 0.55 & 7.3 & 2.7 & 10.6 & 16.4 & 64.9 & 0.0 \\
\hline & $10-20$ & 5.5 & 5.6 & 4.9 & 0.0 & 0.65 & 7.8 & 2.9 & 11.3 & 16.3 & 69.6 & 0.0 \\
\hline \multirow{2}{*}{ Capitão } & $0-10$ & 8.3 & 3.7 & 5.3 & 0.0 & 0.44 & 7.1 & 2.1 & 9.7 & 15.0 & 64.5 & 0.0 \\
\hline & $10-20$ & 4.2 & 5.0 & 4.9 & 0.0 & 0.25 & 7.0 & 2.1 & 9.3 & 14.3 & 65.4 & 0.0 \\
\hline \multirow{2}{*}{ Santa Izabel } & $0-10$ & 11.5 & 3.9 & 6.2 & 0.0 & 0.25 & 6.4 & 2.3 & 8.9 & 15.2 & 59.1 & 0.7 \\
\hline & $10-20$ & 5.7 & 4.2 & 5.7 & 0.0 & 0.18 & 4.5 & 1.98 & 6.7 & 12.1 & 53.7 & 1.0 \\
\hline
\end{tabular}

${ }^{*} \mathrm{H}+\mathrm{Al}$ : Potential acidity (Buffer: SMP); $\mathrm{Al}^{3+}$ : Aluminum; $\mathrm{Ca}^{2+}$ : Calcium; $\mathrm{Mg}^{2+}$ : Magnesium (KCl); $\mathrm{K}^{+}$: Potassium; P: Phosphorus (Mehlich 1); S: Sulfur - SO ${ }_{4}^{2-}($ Calcium phosphate); SB: Sum of Bases; CEC: Cation Exchange Capacity; V: Base Saturation; Al: Aluminum saturation. 
Table 2. Chemical soil characterization (micronutrient level. soil pH, and Organic Matter) in each site before installing each trial.

\begin{tabular}{|c|c|c|c|c|c|c|c|c|}
\hline \multirow{2}{*}{ Site } & \multirow{2}{*}{$\begin{array}{l}\text { Depth } \\
(\mathrm{cm})\end{array}$} & \multirow{2}{*}{$\begin{array}{c}\mathrm{pH} \mathrm{CaCl} \\
\left(0.01 \mathrm{~mol} \mathrm{~L}^{-1}\right)\end{array}$} & \multirow{2}{*}{$\begin{array}{c}\mathrm{MO} \\
\left(\mathrm{g} \mathrm{dm}^{-3}\right)\end{array}$} & $\mathrm{Cu}$ & Mn & $\mathrm{Fe}$ & $\mathrm{Zn}$ & B \\
\hline & & & & \multicolumn{5}{|c|}{$\left(\mathrm{mg} \mathrm{dm}^{-3}\right)$} \\
\hline \multirow{2}{*}{ Juvinópolis } & $0-10$ & 5.2 & 30.70 & 4.76 & 1.69 & 22.95 & 1.69 & 0.26 \\
\hline & $10-20$ & 5.4 & 38.44 & 4.29 & 2.38 & 46.71 & 2.38 & 0.31 \\
\hline \multirow{2}{*}{ Capitão } & $0-10$ & 5.3 & 33.02 & 10.86 & 4.06 & 22.65 & 4.06 & 0.31 \\
\hline & $10-20$ & 5.1 & 24.51 & 10.03 & 2.85 & 30.02 & 2.85 & 0.35 \\
\hline Santa Izabel & $0-10$ & 4.8 & 37.41 & 5.31 & 15.42 & 54.56 & 3.51 & 0.24 \\
\hline
\end{tabular}

* Soil pH (Calcium Chloride); O.M.: Organic Matter (Dichromate), Fe: Iron, Mn: Manganese; Cu: Copper; Zn: Zinc (Mehlich); B: Boron (HCl 0,05 N).

Table 3. Description of the technical characteristics of the foliar fertilizers utilized in the trials.

\begin{tabular}{|c|c|c|}
\hline Product & Guaranteed (\%) related to the volume & Dose ha-1 \\
\hline $\mathrm{A}$ & $N^{*}: 32$ & $5.0 \mathrm{~L}$ \\
\hline B & $\mathrm{N}: 33$ & $5.0 \mathrm{~L}$ \\
\hline $\mathrm{C}$ & N: 1.73; K: 5; S: 2.1; B: 0.08; Fe: 0.49; Mn: 1.0; Zn: 2.43; Organic Carbon: 3.5 & $0.23 \mathrm{~L}$ \\
\hline $\mathrm{D}$ & N: 8; P: 5; K: 1.0; Mg: 0.5; S: 1; Mn: 1.5; Mo: 0.01; Zn: 0.5 B: 0.5; Aa: 3 & $2.0 \mathrm{~L}$ \\
\hline$E^{* *}$ & $\mathrm{~K}: 50 ; \mathrm{S}: 16$ & $1.6 \mathrm{~kg}$ \\
\hline $\mathrm{F}$ & $P: 40 ; K: 50 ; A a: 3$ & $0.33 \mathrm{~L}$ \\
\hline G & B: 2.5; Cu: 4; K: 2.4; N: 4; P: 7.5; Aa: 3 & $0.33 \mathrm{~L}$ \\
\hline $\mathrm{H}$ & N: $10 ;$ S: 11.4 & $2.0 \mathrm{~L}$ \\
\hline
\end{tabular}

*N: nitrogen; P: phosphorus; K: potassium; S: sulfur; Mg: magnesium; B: boron; Fe: iron; Mn: manganese; Zn: zinc; Mo: molybdenum; Cu: copper; Aa: amino acids (glutamic acid). ** The commercial presentation of product $E$ is in the solid form (soluble powder).

With two levels, the second factor was the two application times, corresponding to the growth stages R2 (full bloom) and R5 (beginning seed). For the statistical analysis, the application times were considered the main plot in a split-plot system. The 18 treatments $(9 \times 2)$ originated by combining the nine levels from the foliar fertilizers and the two application times. The 54 experimental units (E.U.) (18 treatments $\times$ three replications) consisted of seven seeding rows, with $0.45 \mathrm{~m}$ row spacing and six meters of length, totalizing an area of $18.9 \mathrm{~m}^{2}$ each E.U. The observation units (O.U.) consisted of the five central rows, the two outer rows, and a meter in each extremity of the plot eliminated, totalizing $9.0 \mathrm{~m}^{2}$ of the experimental area.

The tested foliar fertilizers' application was manual, with a $\mathrm{CO}_{2}$ propelled back boom, always during the morning with low dew on the plant leaves, and relative humidity around $70 \%$. The used nozzles were from the flat fan jet type, model 110.03 , with a ceramic tip, pressure of $40 \mathrm{Lb}$ inches ${ }^{-2}$, and spray solution flow of $250 \mathrm{~L} \mathrm{ha}^{-1}$, providing the full coverage of the sprayed leaves. The use of non-ionic adjuvants was following each foliar fertilizer label. The other cultural practices needed during the season were applied with machinery, using tractor sprayers. Harvest was done on February $8^{\text {th }}, 20^{\text {th }}$, and $28^{\text {th }}$ in Juvinópolis, Capitão, and Santa Izabel.

The response variables were prevenient from the following evaluations: a) Total chlorophyll index (TCI): determined 15 days after the application of the foliar fertilizer in each treatment, using a SPAD meter from the commercial ClorofiLOG ${ }^{\circ}$ model CLF 1030, manufactured by Falker Automação Agrícola. Those measurements were made in three points of three leaves from the medium third of the plant, with three replications/plants per treatment. Results were expressed in non-dimensional units; b) Grain Yield (Yield): determined by the harvest and threshing of four rows from each O.U., with $4 \mathrm{~m}$ length, totalizing a harvested area $7.2 \mathrm{~m}^{-2}$. To calculate yield after threshing, the moisture level of the grains were adjusted $13 \%$, also discounting the impurities, being the result expressed in $\mathrm{kg} \mathrm{ha}^{-1}$; c) Thousand Grain Mass (TGM): determined in the UTFPR Seeds Laboratory in Dois Vizinhos, in a $0.001 \mathrm{~g}$ precision scale, obtaining the average value from eight sub-samples of 100 grains, followed by the interpolation of that value to 1.000 grains, with the result expressed in grams; d) Number of pods per plant (NPP): were collected 10 random plants inside the U.O., where the pod number was counted followed by the calculation of the average number of pods per plant; e) Number of grains per pod (NGP): the plants used to the determination of NPP had their grains counted and after divided to the numbers of pods per each plant, then averaged to the ten sampled plants; f) Number of grains per plant (NGP): the total number of grains in the same 10 sampled plants from the previous evaluations were counted; g) Plant height (P.H.): measured in 10 random plants in the O.U., from the soil surface until the top of the plants, being the result presented as the average of those plants, in centimeters; h) Crude Protein Concentration (C.P.): determined in the Bromatology Laboratory at UTFPR in Dois Vizinhos, according to the Weende method, quoted by Silva (1990), being the results expressed as dry matter percentage; i) Grain oil level or ether extract (O.L.): determined in the Bromatology Laboratory at UTFPR in Dois Vizinhos, according, methodology proposed by AOAC (1980), being the results expressed as dry matter percentage.

After collection, the data was submitted to the normality test of Lilliefors to the verification of homoscedasticity. When the model met the model's assumptions, the dataset was submitted to the analysis of variance, and the Duncan test compared the treatment means with a $5 \%$ probability level $(p<0.05)$. 


\section{Results and Discussion}

There was no effect among the foliar fertilizers to the different studied sites regarding the total chlorophyll index (TCI). However, there was a significant difference to the Capitão and Santa Izabel sites' application time, being that in both, the application in R2 resulted in higher TCl (Table 4). Younger leaves have more chlorophyll quantity, an important pigment of photosynthesis (Li et al., 2018), which may have influenced the result when applied in R2 regarding R5.

The quantification of chlorophyll is essential in fertilization practice studies. Once this pigment is associated with increasing the plants' photosynthetic efficiency and, consequently, plants' growth and adaptability in different environments (Silva et al., 2011; Fonseca et al., 2012). Silva et al. (2017) found that the application of macro and micronutrients in the vegetative time of soybean increased the total chlorophyll content in all treatments regarding the control. However, in this study, there was no increase in the chlorophyll indexes with foliar fertilizers. Moreira et al. (2017) found similar results as a function of foliar nitrogen applied to soybean. However, it is essential to reiterate that the quantification of chlorophyll was given 15 days after applying the different fertilizers, probably allowing that part of the nutrients, mainly nitrogen, were remobilized in the plant as a function of growth. The average TCl decreased from R2 to R5 across the treatments, which can support the idea of nitrogen remobilization due to plant growth.

For thousand-grain mass (TGM), there was an effect on the different application times to the applied foliar fertilizers (Table 5). In the comparison between times, it was observed that from the nine used products, for four fertilizers, the R2 application time presented higher thousand-grain mass, without having differences between times and the check and product $\mathrm{C}$. The treatments with the foliar fertilizers $\mathrm{B}, \mathrm{H}$, and $D$ the applications at R5 were superior.

In the first time the treatments $F$ (Phosphorus: 40\%; Potassium: 50\%; Amino acid: 3\%), G (Boron: 2.5\%; Copper:

Table 4. Three sites mean comparisons for total chlorophyll index of soybean crop treated with different foliar fertilizers at two different times in the reproductive growth stages.

\begin{tabular}{ccccc}
\hline Product & Juvinópolis & Capitão & Sta. Izabel & Average \\
\hline Check & 59.9 & 62.2 & 58.8 & 60.3 \\
A & 59.5 & 59.9 & 60.7 & 60.0 \\
B & 60.9 & 60.9 & 59.7 & 60.5 \\
C & 62.6 & 60.4 & 59.6 & 60.9 \\
D & 60.2 & 60.6 & 59.6 & 60.1 \\
E & 59.9 & 60.8 & 60.0 & 60.2 \\
F & 60.8 & 61.6 & 59.0 & 60.5 \\
G & 61.6 & 61.5 & 60.1 & 61.1 \\
\hline H & 60.4 & 60.0 & 59.4 & 59.9 \\
\hline Time & & & & \\
R2 & $60.6 \mathrm{a}$ & $62.5 \mathrm{a}$ & $60.7 \mathrm{a}$ & $61.3 \mathrm{a}$ \\
\hline R5 & $60.7 \mathrm{a}$ & $59.2 \mathrm{~b}$ & $58.6 \mathrm{~b}$ & $59.7 \mathrm{~b}$ \\
\hline Average & 60.6 & 60.9 & 59.7 & 60.4 \\
\hline CV (\%) & & 3.8 & & \\
\hline
\end{tabular}

In the column, the means followed by the same lowercase letter do not differ statistically by the Duncan test at $p>0.05$.
Table 5. Mean comparison of the average of the three sites to the thousand grain mass (TGM) of the soybean crop treated with foliar fertilizers at two different times in the reproductive growth stages.

\begin{tabular}{ccccc}
\hline \multicolumn{5}{c}{ MMG (g) } \\
\hline \multirow{2}{*}{ Product } & \multicolumn{5}{c}{ Application time } \\
\cline { 2 - 6 } & \multicolumn{2}{c}{ R2 } & R5 & Average \\
\hline Check & 170.3 & Acd & $170.3 \quad \mathrm{Ac}$ & 170.3 \\
A & 171.9 & $\mathrm{Abc}$ & $167.3 \mathrm{Bd}$ & 169.6 \\
B & 170.5 & $\mathrm{Bcd}$ & $176.8 \mathrm{Aa}$ & 173.6 \\
C & 169.1 & $\mathrm{Ad}$ & $170.3 \mathrm{Ac}$ & 169.7 \\
D & 168.5 & $\mathrm{Bd}$ & $171.6 \mathrm{Abc}$ & 170.1 \\
E & 172.8 & $\mathrm{Ab}$ & $167.7 \mathrm{Bd}$ & 170.2 \\
F & 175.1 & $\mathrm{Aa}$ & $167.6 \mathrm{Bd}$ & 171.3 \\
G & 173.0 & $\mathrm{Ab}$ & $166.7 \mathrm{Bd}$ & 169.9 \\
H & 170.5 & $\mathrm{Bcd}$ & $173.4 \mathrm{Ab}$ & 171.9 \\
Average & 171.3 & 170.2 & 170.7 \\
CV (\%) & \multicolumn{5}{c}{3.8} \\
\hline
\end{tabular}

Means followed by the same letter, lowercase in the column and uppercase in the rows, do not differ statistically by the Duncan test at $p>0.05$.

4\%; Potassium: 2.4\%; Nitrogen: 4\%; Phosphorus: 7.5\%; Amino acid: $3 \%$ ) and E (Potassium: 50\%; Sulfur: $16 \%$ ) significantly differ from the untreated check, being that product $F$ presented an increment of $2.75 \%$ in TGM in relation to the check. In the second application time, product B (Nitrogen: $33 \%$ ) was higher than the others, with an increase of $3.7 \%$ in the mass than the check. Nitrogen is the nutrient with the highest demand for soybean. Each ton of grains produced the need is $80 \mathrm{~kg}$ of N (Santos Neto et al., 2013), and when applied after flowering, this nutrient is usually partitioned to the grain (Zimmer, 2012). However, the efficiency of side-dress nitrogen application is due to a diversity of factors, as the soybean variety, the symbiosis efficiency, the source of nitrogen used, the seeding date, soil type, and weather. Although some of the foliar fertilizers, e.g., products $C, D, G$, and $H$, have low $N$ concentrations in their formulations in the present scientific investigation. Considering that the application rates were not high on an area basis, the effects of $\mathrm{N}$ in this occasion were more likely to be a function of the permeability of the other applied nutrients to the cell interior than the nutritional effect of the nutrient by itself.

Studying the application of supplemental nitrogen via foliar application in soybean, dry bean, and corn, Pacentchuk et al. (2014) verified that the thousand-grain mass did not significantly differ by applying the nitrogen foliar fertilizer in the V4, R1, and R4 growth stages. However, the fertilizer application at the beginning of bloom (R6) provided the highest thousand-grain mass in the dry bean crop. Musskopf \& Bier (2010), in studies made with the application of calcium and boron in the R1 and R3 soybean stages, observed significant results in the numbers of pods. However, an increment in seed weight was not observed.

The variables P.H., NGP, NPP, NGP, and Yield did not present a significant difference across products and application times (Table 6). It is worth highlighting that even though there was a significant response to time and foliar fertilizers to TGM, it 
Table 6. Mean comparison of the average of the three sites to the plant height (P.H.), number of grain per pod (NGP), number of pods per plant (NPP), number of grains per plant (NGP), and yield of the soybean crop treated with foliar fertilizers in two in two different times in the reproductive growth stages.

\begin{tabular}{|c|c|c|c|c|c|}
\hline \multirow{2}{*}{ Product } & \multirow{2}{*}{$\begin{array}{l}\text { P.H. } \\
(\mathrm{cm})\end{array}$} & NGP & NPP & NGP & \multirow{2}{*}{$\begin{array}{c}\text { Yield } \\
\left(\mathrm{kg} \mathrm{ha}^{-1}\right)\end{array}$} \\
\hline & & \multicolumn{3}{|c|}{ (n.) } & \\
\hline Check & 104.1 & 2.26 & 40.9 & 92.5 & 3602 \\
\hline A & 103.1 & 2.34 & 43.5 & 100.8 & 3596 \\
\hline B & 104.8 & 2.31 & 42.0 & 97.0 & 3708 \\
\hline C & 103.2 & 2.32 & 43.0 & 99.3 & 3548 \\
\hline D & 103.6 & 2.30 & 42.7 & 97.6 & 3634 \\
\hline$E$ & 103.2 & 2.33 & 41.6 & 97.2 & 3722 \\
\hline $\mathrm{F}$ & 104.5 & 2.34 & 42.1 & 98.4 & 3841 \\
\hline G & 104.0 & 2.32 & 41.5 & 96.0 & 3700 \\
\hline $\mathrm{H}$ & 103.5 & 2.30 & 41.7 & 95.9 & 3719 \\
\hline \multicolumn{6}{|l|}{ Time } \\
\hline $1^{\text {st }}$ & 104.1 & 2.31 & 42.4 & 97.63 & 3862 \\
\hline $2^{\text {nd }}$ & 103.4 & 2.31 & 41.8 & 96.76 & 3790 \\
\hline Average & 103.7 & 2.31 & 42.1 & 97.19 & 3826 \\
\hline CV (\%) & 2.9 & 3.5 & 13.8 & 16.0 & 6.5 \\
\hline
\end{tabular}

was not enough to influence the crop yield. Probably, because various elements determine soybean yield, as the average number of plants per area, numbers of pods per area, number of grains per pod, and average grain weight, being the number of grains per area the factor of the highest importance to the soybean yield (Thomas et al., 1998). The present study observed no effect of the treatments on the number of grains per plant or yield, which could be linked to the adequate level of the soil's nutrients, which, together with fertilization at planting, supplied the crop requirements.

The application of calcium-and-boron-based foliar fertilizers in the dose of $3 \mathrm{~L} \mathrm{ha}^{-1}$, independent of growth stage (R1, R2, R3, and R4), did not influence the yield components nor the grain yield of soybean (Seidel \& Basso, 2011). Similar results were obtained by Muraro et al. (2017), who did not observe foliar fertilizers' effect between the application stages (R5.2 and R6) on soybean yield. Craft et al. (2019) concluded that soybeans had a minimal yield response to nitrogen applied both in the soil and in a foliar way. Similar results were found by Nakao et al. (2018) in which the foliar application of $B$ and $\mathrm{Zn}$ did not improve the yield components and yield of soybean seeds.

In contrast, Mandić et al. (2015) studying the effects of foliar fertilization with nitrogen-based products and nitrogen combined with other macro and micronutrients in the quantitative characteristics (plant height, first pod height, number of nodes per plant, number of pods per plant, number of grains per plant, grain yield per plant, thousand-grain mass and grain yield) of two soybean varieties found significant increases in the values for all evaluated characteristics. Silva et al. (2017) found that Ca and B's application in the flowering of soybeans and $\mathrm{K}, \mathrm{Mg}, \mathrm{S}$, and $\mathrm{B}$ in the grain filling stage increased production. The discrepancy between the results found is often associated with adequate soil fertility levels, thus meeting the crop's needs.

To the variables related to grain quality, crude protein (C.P.), and oil level (O.L.), was not observed a significant interaction or an isolated effect across the studied factors. However, there was significance regarding the evaluated sites, which will be demonstrated (Table 7), although without statistical comparison, as it was not the study's objective. Different sources and rates of foliar fertilizer application with $\mathrm{N}$ did not affect the protein and oil content and the seeds' nutritional status (Moreira et al., 2017).

Based on the results of the current study and the presented discussions referred to various authors that had evaluated foliar fertilization, it is verified that there are still controversies about this theme, for the application time as well as for the different nutrients provided, is often justified by the adequate level of those nutrients in the soil. This way, studies based on nutrient deficiency situations should be considered to elucidate the subject and countersign the increase in the yield components and final grain yield of the crop, and consequently, justify using foliar fertilizers.

Table 7. Three sites percentage average of the variable of dry mass crude protein (C.P.) and oil (O.L.) in soybean grain treated with foliar fertilizers in two in two different times in the reproductive growth stages.

\begin{tabular}{|c|c|c|c|c|c|c|c|c|}
\hline \multirow{2}{*}{ Product } & \multicolumn{4}{|c|}{ CP (\%) } & \multicolumn{4}{|c|}{ O.L. (\%) } \\
\hline & Juvinópolis & Capitão & Sta Izabel & Average & Juvinópolis & Capitão & Sta Izabel & Average \\
\hline Check & 37.4 & 37.9 & 36.9 & 37.4 & 16.0 & 20.5 & 17.6 & 18.0 \\
\hline A & 38.2 & 38.5 & 38.8 & 38.5 & 16.5 & 20.9 & 16.9 & 18.1 \\
\hline C & 36.6 & 39.0 & 38.3 & 38.0 & 16.3 & 20.5 & 17.6 & 18.1 \\
\hline $\mathrm{D}$ & 36.4 & 37.9 & 38.6 & 37.6 & 16.7 & 20.2 & 16.9 & 17.9 \\
\hline G & 38.4 & 39.4 & 36.8 & 38.2 & 16.4 & 20.7 & 16.9 & 18.0 \\
\hline $\mathrm{H}$ & 38.2 & 38.9 & 38.2 & 38.4 & 16.3 & 19.7 & 17.5 & 17.8 \\
\hline \multicolumn{9}{|l|}{ Time } \\
\hline R2 & 37.8 & 38.4 & 38.3 & 38.2 & 16.2 & 20.3 & 17.2 & 17.9 \\
\hline R5 & 36.9 & 38.5 & 38.3 & 37.9 & 16.3 & 20.5 & 17.2 & 18.0 \\
\hline Average & 37.3 & 38.5 & 38.3 & 38.0 & 16.3 & 20.4 & 17.2 & 18.0 \\
\hline
\end{tabular}




\section{Conclusions}

Plant height, total chlorophyll index, and grain quality were not affected by the foliar fertilizers studied.

Thousand-grain mass responded to the foliar product and the application time. However, no effect in final yield was observed, possibly because of the indirect effect of low macronutrient doses, such as nitrogen, on the absorption of the micronutrients present in the tested foliar fertilizers.

\section{Compliance with Ethical Standards}

Author contributions: Conceptualization: FRM, JCP; Data curation: FRM; Formal analysis: ESV; Investigation: FRM, FRMa; Project administration: JCP; Supervision: JCP; Visualization: CD; Writing - original draft: VRF; Writing - review \& editing: $\mathrm{CD}, \mathrm{JCP}$.

Conflict of interest: The authors declare that there are no conflicts of interest that can influence the article.

Funding: The authors declare that there are no sources of funding to carry out the research.

\section{Literature Cited}

Association of Official Analytical Chemists - AOAC. Official methods of analysis. 13th. ed. Washington: AOAC, 1980.

Batista, V. V.; Adami P. F.; Link, L.; Rabelo, P. R.; Rosa, L. C. Eficiência de diferentes fertilizantes foliares em três cultivares de soja. Revista Técnico Científica do CREA-PR, n. 9, 2017. http://creaprw16. crea-pr.org.br/revista/Sistema/index.php/revista/article/ download/235/198. 22 Jun. 2020.

Buratto, W.; Buratto, W.; Oliveira, A. M.; Oliveira, R.; Caione, G.; Seben Junior, G. F. Aplicação foliar de nitrogênio na soja em diferentes fases fenológicas e inoculação com Bradyrhizobium japonicum. Nativa, v. 6, n. 4, p. 333-337, 2018. https://doi.org/10.31413/ nativa.v6i4.5227.

Campo, R. J.; Araujo, R. S.; Hungria, M. Molybdenum-enriched soybean seeds enhance $\mathrm{N}$ accumulation, seed yield, and seed protein content in Brazil. Field Crops Research, v.110, n. 3, p.219224, 2009. https://doi.org/10.1016/j.fcr.2008.09.001.

Craft, J. C.; Lindsey, L. E.; Barker, D. J.; Lindsey, A. J. Quantification of soybean leaf senescence and maturation as impacted by soil- and foliar-applied nitrogen. Crop, Forage \& Turfgrass Management, v.5, n.1, p. 1-8, 2019. https://doi.org/10.2134/cftm2018.07.0051.

Fonseca, P. R. B.; Fernandes, M. G.; Dutra, F.; Souza, T. A.; Pontim, B.C.A. Uso do SPAD-502 na avaliação dos teores foliares de clorofila, em híbridos de milho (Zea mays L.) bt e isogênico. Revista Verde, v.7, n. 1, p. 56-60, 2012. https://www.gvaa.com.br/revista/index.php/ RVADS/article/view/1087/1068. 12 Jun. 2020.

Gai, Z.; Zhang, J.; Li, C. Effects of starter nitrogen fertilizer on soybean root activity, leaf photosynthesis and grain yield. Plos One, v. 12, n. 4, e0174841, 2017. https://doi.org/10.1371/journal. pone. 0174841 .

Kahraman, A. Nutritional value and foliar fertilization in soybean. Journal of Elementology, v. 22, n. 1, p. 55-66, 2017. http://jsite. uwm.edu.pl/articles/view/1106/. 09 Jun. 2020.
Li, X.; Xiao, J.; He, B. Remote sensing of environment chlorophyll fluorescence observed by OCO-2 is strongly related to gross primary productivity estimated from flux towers in temperate forests. Remote Sensing of Environment, v. 204, p. 659-671, 2018. https://doi.org/10.1016/j.rse.2017.09.034.

Malavolta, E.; Vitti, G. C.; Oliveira, S. A. Avaliação do estado nutricional das plantas: Princípios e aplicações. Piracicaba: POTAFOS, 1997. 319p.

Mandić, V.; Simić, A.; Krnjaja, V.; Bijelić, Z.; Tomić, Z.; Stanojković, A.; Ruzić Muslić D. Effect of foliar fertilization on soybean grain yield. Biotechnology in Animal Husbandry, v.31, n.1, p 133-143, 2015 https://doi.org/10.2298/BAH1501133M.

Marcon, E. C.; Romio, S. C.; Maccari, V. M.; Klein, C.; Lájus, C. R. Uso de diferentes fontes de nitrogênio na cultura da soja. Thema, v. 14 n. 2 p. 298-308, 2017. https://doi.org/10.15536/ thema.14.2017.298-308.427.

Meschede, D. K.; Braccini, A. De L. E.; Braccini, M. do C. L.; Scapim, C. A.; Schuab, S. R. P. Rendimento, teor de proteínas nas sementes e características agronômicas das plantas de soja em resposta à adubação foliar e ao tratamento de sementes com molibdênio e cobalto. Acta Scientiarum. Agronomy, v. 26, n.2 139-145, 2008. https://doi.org/10.4025/actasciagron.v26i2.1874.

Moreira, A.; Moraes, L. A. C.; Schroth, G.; Becker, F. J.; Mandarino, J. M. G. Soybean yield and nutritional status response to nitrogen sources and rates of foliar fertilization. Agronomy Journal, v. 109, n.2, p.629-635, 2017. https://doi.org/10.2134/ agronj2016.04.0199.

Mourtzinis, S.; Kaur, G.; Orlowski, J. M.; Shapiro, C. A.; Lee, C. D.; Wortmann, C.; Holshouser, D.; Nafziger, E. D.; Kandel, H.; Niekamp, J.; Ross, W. J.; Lofton, J.; Vonk, J.; Roozeboom, K. L.; Thelen, K. D.; Lindsey, L. E., Staton, M.; Naeve, S. L.; Casteel, S. N.; Wiebold, W. J.; Conley, S. P. Soybean response to nitrogen application across the United States: A synthesis-analysis. Field Crops Research, v. 215, p. 74-82, 2018. https://doi.org/10.1016/j.fcr.2017.09.035.

Muraro, D. S.; Basso, C. J.; Aguiar, A. C. M. Efeito de adubações foliares na qualidade fisiológica e rendimento da soja. Enciclopédia Biosfera, v.14 n.25; p.223-233, 2017. https://doi.org/10.18677/ EnciBio_2017A44.

Musskopf, C.; Bier, V. A. Efeito da aplicação de fertilizante mineral cálcio e boro via foliar na cultura da soja (Glycine max). Cultivando o Saber, v. 3, n. 4, p. 83-91, 2010. https://www.fag.edu.br/upload/ revista/cultivando_o_saber/592c4c1ea18a3.pdf. 22 Jun. 2020.

Nakao, A. H.; Costa, N. R.; Andreotti, M.; Souza, M. F. P.; Dickmann, L.; Centeno, D. C.; Catalani, G. C. Características agronômicas e qualidade fisiológica de sementes de soja em função da adubação foliar com boro e zinco. Cultura Agronômica, v.27, n.3, p. 312-327, 2018. https://doi.org/10.32929/2446-8355.2018v27n3p312-327.

Pacentchuk, F.; Novakowiski, J.H.; Novakowiski, J.H; Sandini, I.E. Nitrogênio complementar via foliar nas culturas do milho, soja e feijão: doses e estádios fenológicos de aplicação. Revista Plantio Direto, n.143-144, p. 28-34, 2014.

Possenti, J. C.; Villela, F. A. Efeito do molibdênio aplicado via foliar e via sementes sobre o potencial fisiológico e produtividade de sementes de soja. Revista Brasileira de Sementes, v. 32, n. 4, p.143150, 2010. https://doi.org/10.1590/S0101-31222010000400016. 
Santos Neto, J.T.; Lucas, F.T.; Fraga, D.F.; Oliveira, L.F.; Pedroso Neto, J.C. Adubação nitrogenada, com e sem inoculação de semente, na cultura da soja. FAZU em Revista, n. 10, p. 8-12, 2013.

Seidel, E.P.; Basso, W.L. Adubação foliar a base de cálcio e boro no cultivo da soja (Glycine max). Scientia Agraria Paranaenis, v. 11, n 2, p 75-8, 2012. https://doi.org/10.18188/1983-1471/sap. v11n2p75-81.

Silva, D. J. Análise de alimentos: método de Weende (Métodos químicos e bioquímicos). Viçosa: Imprensa Universitária UFV, 1990. 165p.

Silva, M.C.C., Coelho, F.S., Braun, H., Fontes, P.C.R. Índice SPAD em função de diferentes horários e posições no folíolo da batata sob fertilização nitrogenada. Revista Ciência Agronômica, v. 42, n. 4, p. 971-977, 2011. https://doi.org/10.1590/S180666902011000400020 .
Silva, N. F.; Clemente, G. S.; Teixeira, M. B.; Soares, F. A. L.; Cunha, F. N.; Azevedo, L. O. S. Use of foliar fertilizers for the specific physiological management of different soybean crop stages. American Journal of Plant Sciences, v. 8, n. 4, p. 810, 2017. https://doi.org/10.4236/ajps.2017.84056.

Taiz, L.; Zeiger, E.; Moller, I.M.; Murphy, A. Fisiologia e desenvolvimento vegetal. Porto Alegre: Artmed, 2017. 888p.

Thomas, A. L.; Costa, J. A.; Pires, J. L. Rendimento de grãos de soja afetado pelo espaçamento entre linhas e fertilidade do solo. Ciência Rural, v.28, n.4, p.543-546, 1998. https://doi. org/10.1590/S0103-84781998000400002.

Zimmer, P. D. Fundamentos da qualidade da semente. In: Peske, S. T.; Villela, F. A.; Meneghello, G. E. (Eds.) Sementes: fundamentos científicos e tecnológicos. Pelotas: Ed. Universitária UFPel, 2012. p. 105-160. 